Original research article

\title{
Epidemiology of dorsopathy in the general population of the Czech Republic - a retrospective analysis from the Institute of Health Information and Statistics of the Czech Republic
}

\author{
Andrea Gilchrist ${ }^{1,2}$ *, Andrea Pokorná ${ }^{3}$ \\ ${ }^{1}$ Oxford University Hospitals NHS Trust, Great Britain \\ 2 University of Ostrava, Faculty of Medicine, Department of Nursing and Midwifery, Czech Republic \\ ${ }^{3}$ Masaryk University, Brno, Faculty of Medicine, Department of Nursing and Midwifery, Brno, Czech Republic
}

\begin{abstract}
Aim: This article analyzes the tendency of reported dorsopathies (dorsalgias and intervertebral discs) of the lumbar region in the general population of the Czech Republic.

Methods: Retrospective analysis of data from health registries of the Czech Republic. The participants in the research were individuals who were diagnosed with dorsalgias (MKN codes M54.1, M54.4, M54.5) or with intervertebral disc diseases (ICD codes M51.0, M51.1) in the period from 2010 to 2018. We studied the total number of cases, and the number of hospital admissions and outpatient treatments. The numbers of patients were divided according to sex, age categories and the regions of the patients' place of residence, adjusted per 100,000 citizens of the respective age group or region.

Results: The total number of patients with dorsalgia and intervertebral disc disease showed a growing tendency. The increase in the number of patients with back problems did not manifest itself in the number of hospitalizations. The treatment is transferred to the outpatient sector, and the number of outpatient contacts in patients suffering from backache has been growing over the last eight years. Conclusions: During the analysis we found out that the number of persons suffering from lower back pain in the general population in the Czech Republic was increasing; the care for persons with proved diagnoses of dorsalgia and intervertebral discs diseases is transferring from hospital treatment to outpatient care; and the relations between the occurrence of back pain and a specific profession may not be found in the national health registries.
\end{abstract}

Keywords: Dorsalgia; Dorsopathy; Intervertebral discs; Prevalence

\section{Introduction}

The increase in the number of people suffering from chronic back pain can be seen in many developed countries since the 1950s (Vrba, 2014). Currently, the most common causes of back pain include mechanical disorders and degenerative changes in the musculoskeletal system. In addition, stress, poor quality sleep, mechanical overload, inactivity, obesity and many other psychosomatic causes also play an undeniable role. One of the most natural functions of the musculoskeletal system is movement. As a result of the development of modern technology, in the long term the present population is facing hypokinesis, a sedentary lifestyle with excessive static load and an absence of natural locomotor activity, in particular locomotion. The development of functional and structural musculoskeletal disorders is further supported by defective body posture in conjunction with uneconomical load of the musculoskeletal system (Pastucha et al., 2018).
Lower back pain (LBP) is one of the most common conditions diagnosed by general practitioners and belongs to the most frequent reasons for incapacity to work and disability pension in the Czech Republic and other European countries (Laštovková et al., 2015). Dorsalgia, comprehensively referred to as multi-level spinal disorders, account for $73 \%$ of the causes of temporary disability for work (TWD) in Czech citizens (Bosák and Másilková, 2018).

Sick leave is taken for diverse reasons and the Czech Statistical Office provides an annual overview of cases of sick leave due to illness or injury (Institute of Health Information and Statistics of the Czech Republic, IHIS, 2019). In 2019, temporary incapacity for work recorded in the Czech Republic was the highest in the last ten years: it amounted to 1,914.8 thousand. Furthermore, the analysis made by the Czech Statistical Office shows that there was a year-on-year increase in the cases of incapacity to work by 65.3 thousand (3.5\%). In 2019, for the first time in the last ten years, the number of reported sickness absence exceeded 1.7 million cases. The number

\footnotetext{
* Corresponding author: Andrea Gilchrist, 37 North Way, Oxford, OX3 9ES, Great Britain; e-mail: Andreak.Gilchrist@gmail.com http://doi.org/10.32725/kont.2021.030

Submitted: 2021-03-11 • Accepted: 2021-06-17 • Prepublished online: 2021-06-28 
of cases increased interannually by $3.7 \%$, which represents an increase of 60.9 thousand cases in absolute terms. The total time off work in 2019 was 75,158,722 days, i.e. 5 million days more than in the previous year. On average, one case of temporary incapacity for work due to sickness lasted 41.0 days, while incapacity for work-related accidents was even higher: 56.9 days, and for other injuries: 55.2 days. The increase in sick leave had an economic impact on the Czech Republic. Due to the fact that in 2019 sickness benefits worth CZK 26.7 billion were paid to the insured, which represents almost $70 \%$ of the total expenditure on benefits of the sickness insurance system, the expenditure on sickness benefits increased by CZK 4 billion, i.e. by $17.6 \%$ year-on-year (IHIS ČR, 2019).

Diseases of the musculoskeletal system do not rank first in the annual national analysis of the most common causes of work disability in the Czech population. It should be noted, however, that unlike the most frequently reported respiratory diseases, requiring a two-week work disability on average (Bosák and Másilková, 2018), temporary disability due to diseases of the musculoskeletal system lasts, on average, for more than 2 calendar months (66 days) per case. This category accounted for a third of the total number of days off (23.7 million days), the highest share in a long time, and diseases of the musculoskeletal system clearly lead the way (IHIS ČR, 2019). The seriousness of the issue of the high prevalence of dorsalgia is also reflected in the analysis of reported disability, which very often follows logically from the long-term temporary disability. Diseases of the musculoskeletal system are - when assessing the patient's state of health for the purposes of disability - the most frequent cause of recognition of disability of the first and second degree in the population in the Czech Republic. The analysis shows that dorsalgia, polyarthralgia, coxarthrosis and gonathrosis are listed as the most common primary diagnoses (Bosák and Másilková, 2018).

Considering the fact that mechanical disorders and degenerative changes of the musculoskeletal system represent the largest group of diagnoses that result in people in the Czech Republic being unable to work and therefore applying for disability pensions (Bosák and Másilková, 2018), we also focused on industrial injuries in the Czech Republic with the aim of analyzing the associated correlations between reported industrial injuries and temporary incapacity for work.

The number of work-related injuries recorded per number of insured persons in 2019 was the highest since 1998. Between 2010 and 2019, there was a 7-percent increase in the number of insured male persons, while there was a 13-percent increase in the number of insured female persons. In 2019, the most frequently reported source of work-related injuries that led to incapacity for work of more than three days was the "materials, loads, products and machinery components" group (34\%). Furthermore, the most common cause for all types of work-related injuries in 2019 was "poor or insufficient risk assessment". This cause was indicated by the employer on the injury record and therefore quite prevalent, even in previous years (Research Institute of Occupational Safety of the Czech Republic, 2019).

Although injury prevention training for manual handling and the use of lifting equipment is a global competency (Research Institute of Occupational Safety of the Czech Republic, 2016) and ergonomics management tools are considered important throughout the Western world to reduce the risks associated with lifting, moving and shifting loads (Kneafsey el al., 2015), there is still no consistent view in the Czech Republic on the preferred preventive measures (Research Institute of Occupational Safety of the Czech Republic, 2016).

\section{Materials and methods}

The analysis of the research data is part of a large-scale study investigating cross-cultural differences in the prevalence of lower back pain among the general nurse population in the Czech Republic and the United Kingdom. As the issue of prevalence of lower back pain in the general nursing profession in the Czech Republic has not been systematically addressed and lumbar spine injuries are not included in the list of occupational diseases, we conducted an analysis of the prevalence of non-occupational lower back pain in the general population in the Czech Republic.

This study was conducted to analyze the trend of reported dorsalgia and lumbar intervertebral disc disease in the general population of the Czech Republic.

The data source is information from the Institute of Health Information and Statistics of the Czech Republic (IHIS CR, 2019), which is collected within the National Health Information System (NHSIS) and national health registries. The National Register of Covered Health Services (NRCHS) contains data from health insurance companies in inpatient and outpatient care, including complete data on reported diagnoses, procedures and treatments; currently, complete data is available for the period from 2010 to 2018.

To identify dorsopathy, International Classification of Diseases (ICD-10) codes M40-M54 were used in the principal diagnosis for both outpatient and inpatient cases between 2010 and 2018. Given that the focus of the study is lower back pain, the principal diagnoses M40-M54 were further divided into lower back disease, namely dorsalgia, and other intervertebral disc disease.

Dorsalgia was identified based on the following MKN codes:

- M54.1 Radiculopathy of lumbar NS

- M54.4 Lumbago with sciatica

- M54.5 Lower back pain, Lumbar pain, Lower back strain, Lumbago NS

Diseases of other intervertebral discs according to the following ICD codes:

- M51 Diseases of other intervertebral discs

- M51.0+ Disease of lumbar and other intervertebral discs with myelopathy

- M51.1+ Disease of lumbar and other intervertebral discs with radiculopathy

For these categories, both the total number of cases and the number of unique patients, as well as the number of inpatient and outpatient admissions were monitored. In addition, the numbers of patients were broken down by age group and by region of residence of the patient, and then adjusted per 100,000 population of the respective age group or region.

\section{Results}

The trend in the absolute number of patients with dorsalgia (M54.1, M54.4, M54.5) and intervertebral disc disease (M51.0, M51.1) was calculated between 2010 and 2018 and is shown in Charts 1 and 2.

As you can see in Chart 1, the number of patients suffering from dorsalgia increased from 2012 to 2016. The highest increase occurred between 2014 and 2015, when the number of patients increased by approximately 24,000 cases. From 2015 
onwards, the number of cases increased by 10,000 per year and in 2016 the number of patients with dorsalgia reached a peak ( $n=440,996)$ and started declining. In 2018, the reported number of dorsalgia patients was 427,295.

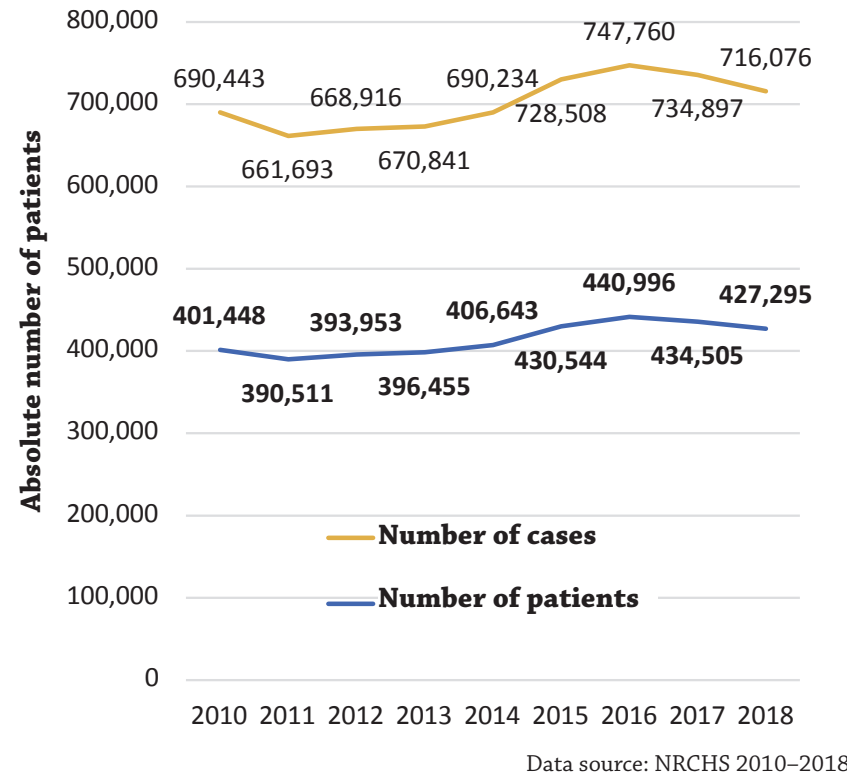

Chart 1. Overview of the number of patients with dorsoalveolar disease for the period 2010-2018

On the other hand, Chart 2 shows that the number of patients with intervertebral disc disease was relatively stable between 2011 and 2013. Thereafter, the number of patients with this disease began to increase by 1,000 patients per year between 2013 and 2017. In 2017, the incidence of intervertebral disc disease peaked with a total of 86,013 patients. The trend did not last long and in 2018 the number of patients dropped to 84,465 .

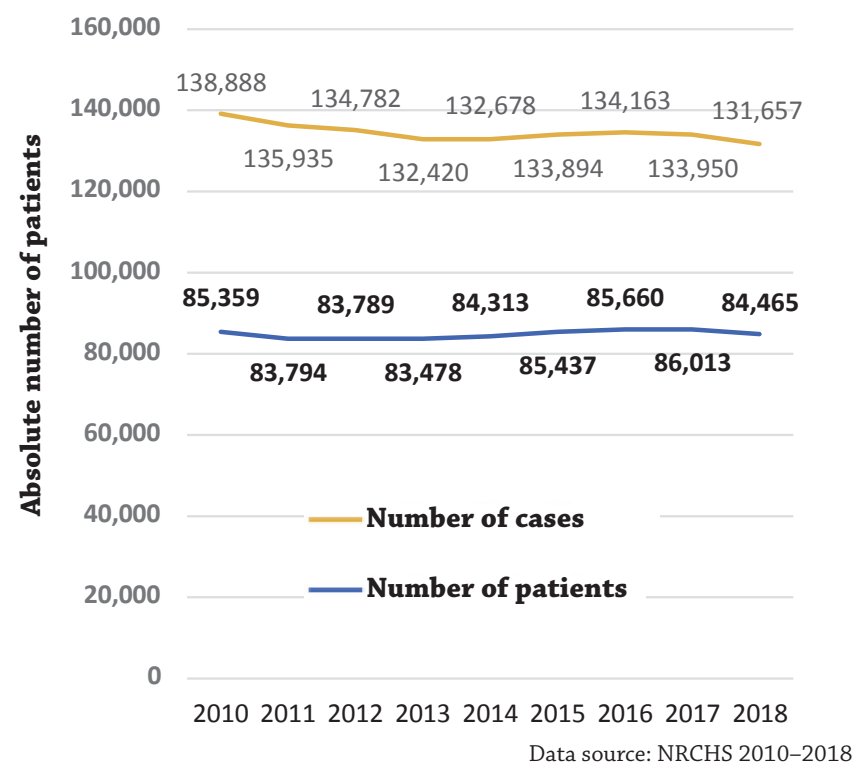

Chart 2. Overview of the number of patients with intervertebral disc disease for the period 2010-2018
Another monitored area was the number of hospitalizations caused by the monitored groups of diseases over the eight-year period.

It is clear from the data obtained that there has been a reduction in the number of hospital admissions for both intervertebral disc disease and dorsalgia. However, the number of outpatient contacts has increased over the study period. The increase in outpatient appointments associated with dorsalgia is demonstrably higher compared to intervertebral disc disease. The upward trend is particularly obvious in 2015, when there was an increase of more than 45,000 reported cases of dorsalgia in just one year.

\section{Demographic profile of patients with dorsalgia and intervertebral disc disease for the period 2010-2018}

When comparing the demographic profiles of the two groups of diseases in 2018, we found that the prevalence of dorsalgia and intervertebral disc disease is identical for both the gender and age of patients, as shown in Charts 3 and 4 .

Men and women account for $46 \%$ and $54 \%$ of all patients with dorsalgia and intervertebral disc disease, respectively. The age profile is similar for men and women, with a slight male predominance until the age of $40-45$ years, when the situation reverses and women predominate.

Chart 3 shows the maximum point of occurrence of dorsalgia, with men already at the age of 40-45 years and women at the age of 55-60 years. Chart 4 shows that intervertebral disc problems peak in both sexes at the age of 55-60 years.

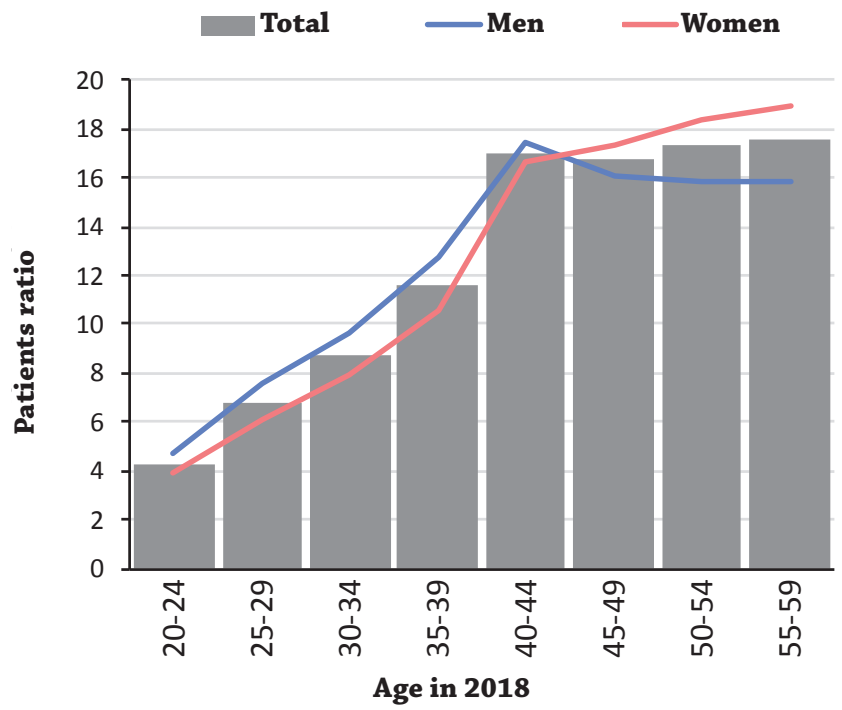

Data source: NRCHS 2010-2018 Patients with dorsalgia in $2018(N=427295)$

Chart 3. Age structure of patients with dorsalgia in 2018

According to data from the National Register of Covered Health Services, in the Czech Republic there were 3,979 patients with dorsalgia and 788 patients with intervertebral disc disease per 100,000 inhabitants in 2018.

The highest standardized incidence of dorsalgia was reported in the Olomouc Region and the lowest in the capital city of Prague. The highest number of patients with intervertebral disc disease was reported in the Ústí nad Labem Region, while the lowest number of cases relative to the population was recorded in the Liberec Region. 


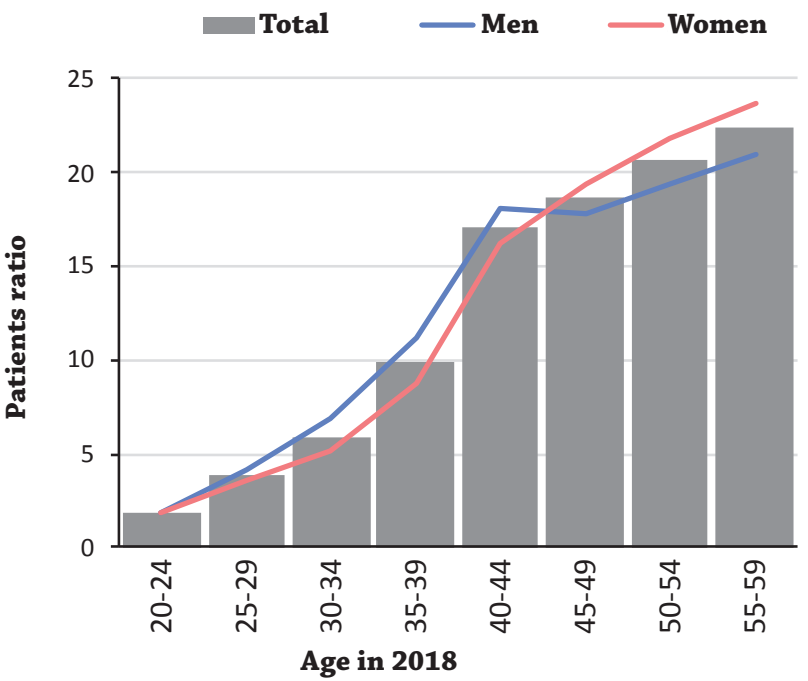

Patients with intervertebrat disc

Chart 4. Age structure of patients with intervertebral disc disease in 2018

\section{Overview of the number of hospital admissions for dorsal and intervertebral disc disease by demographic profile in 2018}

An overview of the number of hospitalizations due to dorsalgia is shown by age of patients in Chart 5 . Dorsalgia was reported in 48 percent of men, while women accounted for 52 percent of patients in 2018. The age profile is similar for men and women with a slight predominance in men up to the age of 40-45 years, when the proportions change and women predominate. The maximum age for those hospitalized by dorsalgia was in the $55-60$ age group.

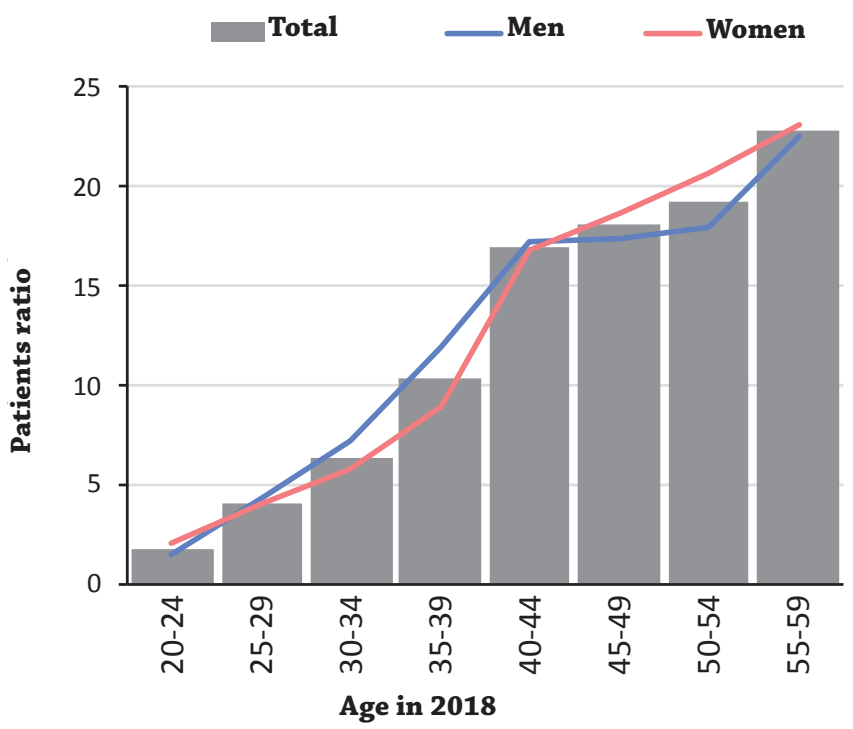

Data source: NRCHS 2010-2018 Patients with dorsalgia in $2018(N=12$ 272)

Chart 5. Demographic profile of hospitalized patients with dorsalgia in 2018
The age structure of patients with intervertebral disc disease is shown in Chart 6. For intervertebral disc disease, men accounted for 51 percent of all hospitalized patients and females for 49 percent. The age profile of hospitalized patients is similar for men and women, with a slight predominance of men up to the age of 40-45 years, when the proportions change and women predominate. Both sexes reach a maximum in the age group of 55-60 years.

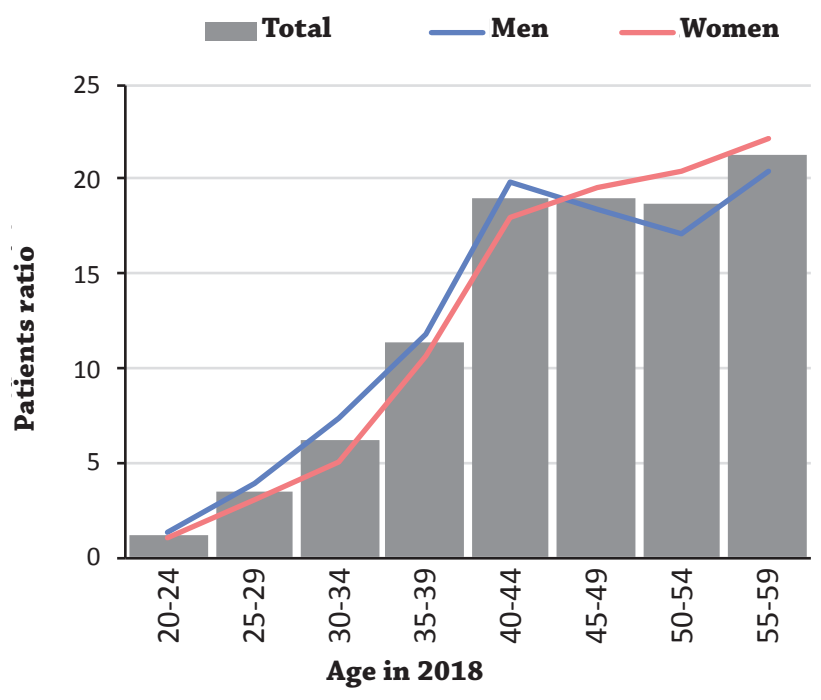

Data source: NRCHS 2010-2018 Patients with intervertebral disc disease in $2018(N=7138)$

Chart 6. Demographic profile of hospitalized patients with intervertebral disc disease in 2018

As you can see in Charts 7 and 8, the number of hospital admissions for dorsal and intervertebral disc disease has been declining over time. In 2018, 12,272 patients with dorsalgia (12 per 100,000 population) and 7,138 patients with intervertebral disc disease (7 per 100,000 population) were hospitalized in the Czech Republic.

35,000

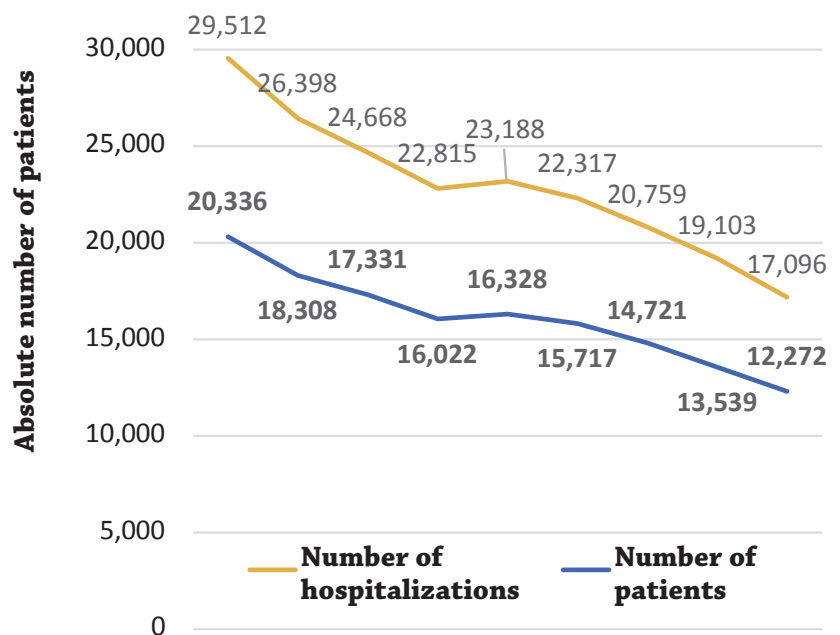

201020112012201320142015201620172018

Data source: NRCHS 2010-2018

Chart 7. Overview of the number of hospitalized patients with dorsalgia in the period 2010-2018 


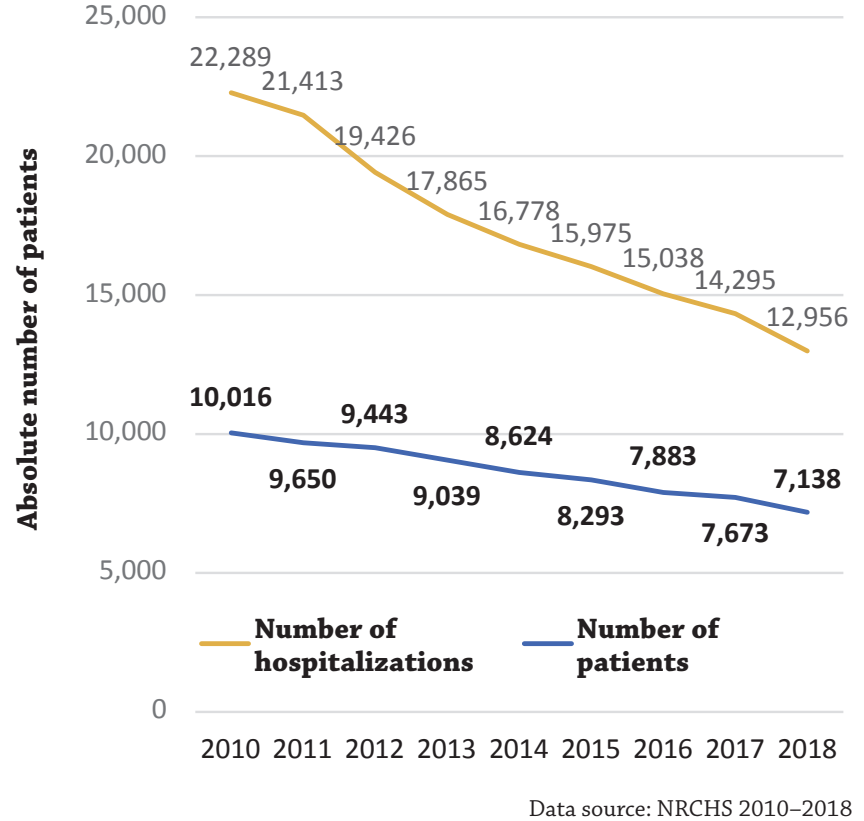

Chart 8. Overview of the number of hospital admissions for intervertebral disc disease in the period 2010-2018

The highest number of hospitalizations in 2018 due to dorsalgia was reported in the Vysočina Region, while the lowest number of cases relative to the population was in the capital city of Prague. Intervertebral disc disease was most frequently reported in the Pilsen Region and the lowest number of cases relative to the population was in the Liberec Region.

\section{Discussion}

By a retrospective analysis of health registries, we found that the total number of patients with dorsalgia and intervertebral disc disease showed an increasing trend, which was particularly significant for dorsalgia.

The incidence of dorsalgia increased from $2012(n=$ $393,953)$ to 2016 ( $n=440,996)$. The highest increase occurred between 2014 and 2015, when the number of patients increased by approximately 24,000 cases. From 2015 onwards, the number of cases increased by 10,000 per year, reaching a peak in 2016 ( $n=440,996)$ before declining. In 2018, the reported number of dorsalgia patients was 427,295.

On the other hand, the number of patients with intervertebral disc disease was relatively stable between 2011 ( $n=$ $83,794)$ and $2013(n=83,478)$. Thereafter, the number of patients with this disease began to increase by 1,000 patients per year between 2013 and 2017. In 2017, the incidence of intervertebral disc disease peaked with a total of 86,013 patients. The trend did not last long; in 2018 the number of patients dropped to 84,465 . The increase in the number of patients with the diseases under study has not been reflected in the number of hospital admissions, with a noticeable decline in hospital admissions over the eight-year period. Nevertheless, there was no decrease in the number of outpatient contacts. Outpatient encounters associated with intervertebral disc disease are relatively stable, but there has been an increase in dorsalgia. Thus it is clear that the number of patients suffering from back pain has not decreased, but rather these patients have drawn on outpatient care rather than inpatient care. The use of sick leave related to dorsalgia and intervertebral disc disease was not part of the analysis performed.

The issue of the economic impact of temporary work disability and disability in the most common musculoskeletal diagnoses (Dorsalgia; Polyarthralgia; Coxarthrosis; Gonarthrosis) has already been addressed by Bosák and Másilková (2018). Their analysis revealed that musculoskeletal disorders are among the most common causes of temporary disability, and they also rank first among newly incurred disabilities in the Czech population. Based on the calculations, it was found that the estimated cost of disability pensions, temporary incapacity for work and loss of social and health insurance amounted to CZK 5,655,418,042 ( $€ 222,741,947)$ in 2014, CZK 6,170,237,616 (€ 243,018,417) in 2015, and CZK 6,850,312,686 ( $€ 269803572$ ) in 2016, which is 21 percent higher than in 2014.

The data presented above proves that diseases of the musculoskeletal system are the most common cause of work disability in the Czech Republic and worldwide. Our research has long focused on the prevalence of back pain in the general nurse population, but data sources from national health registries do not provide information in relation to a particular profession. Various international studies have focused their research on the impact of occupational performance on the prevalence of back pain and have revealed that the lower back is the most vulnerable part of the body in terms of work-related musculoskeletal disease among general nurses in direct patient care (Ellapen and Narsigan, 2014). The prevalence of lower back pain (LBP) appears to be even higher in general nurses than in women of similar age in the general population (D’Agostin and Negro, 2017; Fiter et al., 2018; Hartvigsen et al., 2005). Compared to other health professions, the prevalence of lower back pain has also been shown to be higher in general nurses than in other health professions (Karahan and Bayraktar, 2013). Due to the fact that the Czech Republic does not recognize musculoskeletal lower back pain as a work-related condition, it is therefore still difficult to determine the prevalence of lower back pain and lumbar spine injuries in the nursing profession at a national level (Commission European, 2015). Numerous studies have revealed that persistent lower back pain is the most common reason for nurses' absence from work and is one of the main reasons for a career change or early retirement (Fiter et al., 2018; Simon et al., 2008). Despite the fact that general nurses are usually the most important workforce in the health care system, there is no systematic data collection as to their state of health in the Czech Republic. Similarly, there is little information on how general nurses manage any long-term conditions that might result in a reduction in hours or leaving the job altogether.

Against the background of the aforementioned facts, in 2019 the authors conducted research on the prevalence of musculoskeletal lower back pain and its associated impact on work disability among general nurses in the Czech Republic (Gilchrist and Pokorná, 2021).

Despite the fact that the vast majority of the studied cohort of nurses $n=482$ (85\%) reported lower back pain, which they associated with their occupation, this high incidence did not affect the taking of sick leave. Only 6 percent of the general nurses in the study population reported taking sick leave in the last 12 months due to ongoing problems. An alarming finding was that general nurses in direct care did not seek their GP's help to manage their chronic lower back problems as they accepted frequent back pain as part of their job. Although nurses do not seek the help of a GP, 54 percent reported that 
lower back pain negatively affected the practice of their profession and limited them in performing some nursing activities (Gilchrist and Pokorná, 2021).

The results of foreign research have come to a similar conclusion. They mention presenteeism (sickness presenteeism) as a serious problem, a term used to describe "the phenomenon of people continuing to work despite complaints of ill health that should prompt them to rest and take time off work". Nursing staff, helping professions and elementary school teachers have been found to be at much higher risk of presenteeism, and LBP has been mentioned as the most common issue in studies analyzing presenteeism in the general nursing profession (d'Errico et al., 2013). D'Errico et al. (2013) also described that the work identity, loyalty and concern of workers in the aforementioned professions towards the recipients of their care (patient, client, student) increases the tendency to be at work, despite the presence of illness or pain, and employees work a significant number of days despite difficulties (Skela-Savič et al., 2017).

Despite the undeniable advances in modern medicine, the costs of diseases due to mechanical disorders or degenerative changes in the musculoskeletal system are increasing significantly every year. These costs could be used much more efficiently, for example in the area of prevention, if the system were set up more effectively. Successful company managers have come to understand that investing in occupational health and safety (OHS) is definitely worthwhile, both economically and in terms of creating a reputation as an employer who values good health of their employees. Therefore they support prevention and realize the long-term economic and business benefits. Nevertheless, the problem is that there are still a considerable number of employers who put the economic side of the company first and consider OHS as being more of an economic burden, arguing that the likelihood of an occupational injury or impairment to an employee's health is low, so it is not worth investing time and money in this area (Research Institute of Occupational Safety of the Czech Republic, 2020). Such employees neglect the important fact that it is crucial for the proper functioning of the organization as well as for the economy of any country that the number of disabled persons decreases and, on the contrary, the proportion of persons who re-enter the workforce increases (Bosák and Másilková, 2018; Vrba, 2014).

\section{Conclusions}

From a retrospective analysis of health registries in the epidemiology of dorsalgia and other intervertebral disc diseases in the general population in the Czech Republic between 2010 and 2018, we found that the total number of patients with dorsalgia and intervertebral disc disease showed an increasing trend. The increase in the number of patients with a back disease was not reflected in the number of hospital admissions in the long term. Nevertheless, care is shifting to the outpatient sector, with an increasing number of visits to the General Practices for back pain patients over the eight-year period. There are regional differences in the prevalence of back disorders. It is not possible to establish the relationship between the prevalence of back pain and a specific profession from national health registries, but international studies show that the general nursing profession is considered to be one of the most affected professions.

\section{Ethical aspects and conflict of interests}

A retrospective data analysis was performed in accordance with ethical guidelines. The methodology did not require written consent from any specific individuals. The authors declare that they have no conflict of interests regarding this paper.

\section{Acknowledgements}

The paper was supported by the grant project: Cross-cultural differences in the incidence of lower back pain in general nurses in the Czech Republic and Great Britain - SGS09/LF/20192020, Faculty of Medicine, University of Ostrava.

\section{Epidemiologie dorzopatií u všeobecné populace v České republice - retrospektivní analýza ze zdravotnických registrů}

\section{Souhrn}

Cíl: Cílem je analyzovat trend hlášených dorzopatií (dorzalgií a onemocnění meziobratlových plotének) lumbální části u všeobecné populace v České republice.

Metodika: Retrospektivní analýza dat ze zdravotnických registrů České republiky. Výzkumný soubor tvořily osoby, u kterých byly diagnostikovány dorzalgie (MKN kódy M54.1, M54.4, M54.5) nebo onemocnění meziobratlové ploténky (MKN kódy M51.0, M51.1) v letech 2010-2018. Sledován byl celkový počet př́ipadů, počet hospitalizací a ambulantních ošetření. Počty pacientů byly rozděleny dle pohlaví, věkových kategorií a dle krajů bydliště pacienta i s přepočtem na 100000 obyvatel dané věkové skupiny či daného kraje.

Výsledky: Celkový počet pacientů s dorzalgií a onemocněním meziobratlových plotének vykazoval vzrůstající trend. Nárůst počtu pacientů s onemocněním zad se neprojevil na počtu hospitalizací. Péče je přesouvána do ambulantního sektoru, přičemž za období 8 let počet ambulantních kontaktů u pacientů s bolestmi zad narůstá.

Závěr: V rámci provedené analýzy jsme zjistili, že počet osob trpících bolestmi dolní části zad u všeobecné populace v České republice narůstá. Péče o osoby s vykázanými diagnózami onemocnění dorzalgie a meziobratlových plotének se přesouvá $z$ hospitalizační péče do ambulantní. Z národních zdravotnických registrů nelze zjistit vztah výskytu bolestí zad a konkrétní profese.

Kličová slova: dorzalgie; dorzopatie; meziobratlové ploténky; prevalence 


\section{References}

1. Bosák M, Másilková M (2018). Temporary Work Inability and Invalidity Regarding the Most Frequent Impairments of the Motoric System - Economic Impact on the Czech Republic. Contact 20(3): 298-306. DOI: 10.1016/j.kontakt.2018.08.005.

2. European Commission (2015). EU Strategic Framework on Health and Safety at Work 2014-2020. EU - North Africa Seminar: Strategies for Better Occupational Safety and Health, no. April: 28. [online] [cit. 2021-01-02]. Available from: https://eur-lex.europa.eu/legal-content/EN/TXT/ PDF/?uri=CELEX:52014DC0332

3. D’Agostin F, Negro C (2017). Symptoms and Musculoskeletal Diseases in Hospital Nurses and in a Group of University Employees: A Cross-Sectional Study. Int J Occup Saf Ergon 23(2): 274-284. DOI: 10.1080/10803548.2016.1198092.

4. d'Errico A, Viotti S, Baratti A, Mottura B, Barocelli AP, Tagna M, et al. (2013). Low Back Pain and Associated Presenteeism among Hospital Nursing Staff. J Occup Health 55(4): 276-283. DOI: 10.1539/joh.12-0261-OA.

5. Ellapen TJ, Narsigan S (2014). Work-Related Musculoskeletal Disorders among Nurses: Systematic Review. J Ergon 4: S4. DOI: 10.4172/2165-7556.S4-003.

6. Fiter J, Werdhani RA, Wahyuni S (2018). Effect of Back-Exercise on the Level of Pain and Disability among Hospital Ward Nurses with Subacute and Chronic Nonspecific Low Back Pain. J Physics: Conference Series 1073(6): 1-8. DOI: 10.1088/17426596/1073/6/062027.

7. Gilchrist A, Pokorná A (2021). Prevalence of Musculoskeletal Low-Back Pain among Registered Nurses: Results of an Online Survey. J Clin Nurs (in print). [online] [cit. 2021-02-03]. Available from: https://doi.org/10.1111/jocn.15722

8. Hartvigsen J, Lauritzen S, Lings S, Lauritzen T (2005). Intensive Education Combined with Low Tech Ergonomic Intervention Does Not Prevent Low Back Pain in Nurses. Occup Environ Med 62(1): 13-17. DOI: 10.1136/oem.2003.010843.

9. Institute of Health Information and Statistics of the Czech Republic (IHIS) (2019). Sickness and Injury Incapacity for Work in 2019. Prague. [online] [cited 2021-01-01]. Available from: https://www.czso.cz/csu/czso/pracovni-neschopnost-pronemoc-a-uraz-v-ceske-republice-za-rok-2019

10. Karahan A, Bayraktar N (2013). Effectiveness of an Education Program to Prevent Nurses' Low Back Pain. Workplace Health Saf 61(2): 73-78. DOI: 10.1177/216507991306100205.

11. Kneafsey R, Clifford C, Greenfield S (2015). Perceptions of Hospital Manual Handling Policy and Impact on Nursing Team Involvement in Promoting Patients' Mobility. J Clin Nurs 24(1-2): 289-299. DOI: 10.1111/jocn.12659.

12. Laštovková $A$, Nakládalová $M$, Fenclová $Z$, Urban $P$, Gad'ourek P, Lebeda T, et al. (2015). Low-Back Pain Disorders as Occupational Diseases in the Czech Republic and 22 European Countries: Comparison of National Systems, Related Diagnoses and Evaluation Criteria. Cent Eur J Public Health 23(3): 244-251. DOI: 10.21101/cejph.a4185.

13. Pastucha D, Horák S, Rabelová E, Hubáček P, Hyjánek J, Filipčíková R, Daňková Š (2018). Dorsalgia in a General Practitioner's Office. Med praxi 15(2): 118-120. DOI: 10.36290/ med.2018.018.

14. Research Institute of Occupational Safety of the Czech Republic (2016). Work Environment - Healthcare. Patient Handling in Healthcare. [online] [cited 2021-01-01]. Available from: https:// zsbozp.vubp.cz/pracovni-sprostredi/odvetvi/zdravotnictvi/284manipulace-s- pacienty-ve-zdravotnictvi

15. Research Institute of Occupational Safety of the Czech Republic (2019). Occupational Injuries. [online] [cited 2021-01-01]. Available from: https://zsbozp.vubp.cz/pracovni-urazovost/666pracovni-urazovost-v-ceske-republice-v-roce-2019

16. Research Institute of Occupational Safety of the Czech Republic (2020). Risk Prevention. [online] [cit. 2021-01-01]. Available from: https://zsbozp.vubp.cz/prevence-rizik/661-chcete-liusetrit-vsadte-na-prevenci

17. Simon M, Tackenberg P, Nienhaus A, Estryn-Behar M, Conway PM, Hasselhorn HM (2008). Back or Neck-Pain-Related Disability of Nursing Staff in Hospitals, Nursing Homes and Home Care in Seven Countries-Results from the European NEXT-Study. Int J Nurs Stud 45(1): 24-34. DOI: 10.1016/j. ijnurstu.2006.11.003.

18. Skela-Savič B, Pesjak K, Hvalič-Touzery S (2017). Low Back Pain among Nurses in Slovenian Hospitals: Cross-Sectional Study. Int Nurs Rev 64(4): 544-551. DOI: 10.1111/inr.12376.

19. Vrba I (2014). Differential Diagnosis and Treatment of Back Pain. Internal Med 10(3): 142-145. 